\title{
Validating a Standardized Usability/User-Experience Maturity Model: A Progress Report
}

\author{
Aaron Marcus ${ }^{1}$, Richard Gunther ${ }^{2}$, and Randy Sieffert ${ }^{3}$ \\ ${ }^{1}$ President, Aaron Marcus and Associates, Inc., 1196 Euclid Ave., Suite 1F, \\ Berkeley, CA, 94708 USA \\ Aaron.Marcus@AMandA.com \\ ${ }^{2}$ Principal, Ovo Studios, LLC, 236 High St., Chagrin Falls, OH 44022 \\ rich@ovostudios.com \\ ${ }^{3}$ Principal UX/IxD Designer, Whirlpool Corp., Global Consumer Design, \\ 1800 Paw Paw Ave., MD 6008, Benton Harbor, MI 49022 \\ randall_h_sieffert@whirlpool.com
}

\begin{abstract}
The authors report on ongoing work in developing a usability/userexperience maturity model, in particular, the results of a workshop about this subject held at the Usability Professionals Association 2009 national conference.
\end{abstract}

Keywords: Business, design, experience, maturity, model, usability, user.

\section{Introduction}

Managers of design, analysis, and development in the human-computer interface (HCI) usability, user-experience (UX), and user-interface (UI) communities are developing or altering their programs in reaction to new business models, methods of practice, professional philosophies, and technologies. There is much turmoil, new terminology, and debate about best practices.

Recognizing the importance of understanding key terms and conceptual models of user-experience and being able to describe a model of evolving maturity in developing programs of people and resources to manage this ongoing activity, Gunther [3] organized a workshop on user-experience maturity modeling at the Usability Professionals Association (UPA) national conference in 2006 [3] and 2009 [4], at which Marcus and Sieffert took part.

Because of conflicting publishing deadlines, the exact contents cannot be provided for the HCI International (HCII) 2009 Proceedings, however, the results of the UPA 2009 workshop are available in summarized form from Marcus or Gunther. This paper summarizes the intentions and the expected results of the 2009 workshop and provides a high-level summary of the workshop approach. The authors will present the summary presentation of the UPA 2009 workshop and discuss its implications during this session.

\section{The UPA Workshop}

The UPA workshop brought together approximately 12 top-level managers and directors from large enterprise software companies who are in charge of usability/user-experience 
(U/UX) development. The authors presented these participants with a draft proposed model for assessing the maturity of a usability/user-experience organization. Based on their collective experience, they revised and refined this model. The expected outcome of the event was a revised model suitable for broader publication and review by the usability/user-experience community.

The workshop leaders themselves, individually or collectively have done research, planning, and writing pertaining to measuring the positive business effects of usability and user-centered design, including the following:

- Presented papers at UPA, CHI, and HCII conferences regarding how, when, and where to best deploy user-centered design methodologies.

- Lead/facilitated workshops and tutorials at UPA, CHI, and HCII conferences on the topics of managing user experience and the business of usability.

- Founded UPA's "Usability in the Enterprise" project, and has worked on or spearheaded all initiatives for that group thus far.

- Contributed and consulted on projects for which every penny spent on usability had to be justified and documented, have seen the ill-effects of lack of business-metric tracking in usability organizations.

- Reviewed UPA, CHI, and HCII presentation and tutorial submissions for the past 25 years.

- Members of most major U/UX organizations worldwide for up to 27 years.

- Edit/write for publications about U/UX, including User Experience (UPA) and Interaction (CHI).

- Authored/co-authored approximately 6 books and more than 300 publications.

- Conducted surveys about U/UX practices and trends among U/UX development leaders at major companies worldwide.

- Managed and grew UX teams through business justification even in tight economic conditions.

\subsection{Previous Work on This Topic}

An objective of the workshop was to add to the existing body of knowledge, both principles and techniques, regarding measuring the maturity of U/UX organizations. The report from the workshop in part collates the opinions and experiences of the participants into a collectively validated model for measuring the maturity of U/UX teams. While there have been standards published $[17,18]$ these have gained little traction in the UX community. There have also been a number of articles published on the topic of capability maturity models [for examples see $21,22,23$ ], but there seem to have been few if any workshops or sessions on the topic at CHI, HCII, or UPA conferences.

The difference between these past presentations and the workshop was this: whereas the presentations were mostly case studies specific to an industry, methodology, or product, the workshop instead sought to develop a more general, more valid, and more reliable model, which would be backed up by the experience and knowledge of the workshop's attendees, and possibly generalizable to other types of companies. Once such a model exists, it seems possible to establish a company's level of 
U/UX maturity as an independent metric, in order to better determine if there is a correlation between U/UX maturity and business performance.

\subsection{Participant Selection Criteria}

The authors selected participants based on their work experience, submission of a position paper, and ability/willingness to share their personal work experiences. In general, these participants were upper-level practitioners at enterprise software companies who are responsible for developing and justifying a usability team's organization, discipline-focus, process, and budget, including head count, resource needs, travel, etc. These participants did not need to be U/UX practitioners themselves, as long as they were involved in customer-centered areas of their business, the authors felt that these participants would be able to make a meaningful contribution.

In general, the authors selected participants based on the following criteria:

- Required to have at least seven years experience in the U/UX fields, or in a customer-centered area of their organization.

- Required to have held a management position regarding software development at software development companies or vertical market customer.

- Required to be able, legally, to share their work experiences, business metrics, and processes with the workshop.

- Desired mix of Manager/Directors: Manager/Directors represent a crosssection of company size, geographical location, usability team size, tenure, and budget.

The authors asked the prospective participants to submit a position paper, due one month before the workshop, and to provide details about their work experience, as well as their opinions about the following questions:

- How do you keep track of the impact of your team's work on your company's business performance?

- Has this method changed among the companies for which you have worked or the industries you have served?

- Do you think it is possible to create a standardized model for assessing the maturity of a U/UX organization?

- What do you think is the best way to go about creating such a model?

We believed that members of the U/UX community, including those who might not otherwise attend the UPA 2009 conference, would be interested in the workshop because of the resulting report. We planned to emerge from the workshop with a revision to the initially proposed draft model based on the experience and expert knowledge of the participants. Because this workshop covered a topic of great interest to the U/UX community as a whole, we also believed all who would participate in it would help publicize the results.

\subsection{Pre-workshop Activities}

Prior to the workshop, we provided the participants with the initial proposed model, a glossary that defines the model's terms, and a list of focus areas. We asked that the 
participants familiarize themselves with the model and the focus areas, and come prepared with a list of questions, comments, suggestions, or concerns. The objective of this preparation work was to have all participants share a basic familiarity of the terms and possible model taxonomy so that participants could use the workshop time most effectively.

The authors used the month leading up to the workshop to finalizing the workshop schedule, reviewing participant position papers, selecting and confirming participants, and developing handouts/presentations.

The draft U/UX Maturity Model provided to participants featured the levels of maturity (rows) against UX management practices (columns) as shown in Table 1.

Table 1. Draft U/UX Maturity Model provided to participants

\begin{tabular}{|l|l|l|l|l|l|}
\hline $\begin{array}{l}\text { Management } \\
\text { Practice } \\
\text { Level }\end{array}$ & $\begin{array}{l}\text { UX } \\
\text { Development }\end{array}$ & $\begin{array}{l}\text { Staffing } \\
\text { Resources }\end{array}$ & $\begin{array}{l}\text { Management } \\
\text { Commitment }\end{array}$ & $\begin{array}{l}\text { Organizational } \\
\text { Alignment }\end{array}$ & $\begin{array}{l}\text { Vision \& } \\
\text { Strategy }\end{array}$ \\
\hline 5. Optimized & $\begin{array}{l}\text { Continual } \\
\text { Process } \\
\text { Improvement }\end{array}$ & UX Executive & $\begin{array}{l}\text { Maintenance } \\
\text { Commitment }\end{array}$ & $\begin{array}{l}\text { UX part of } \\
\text { Business } \\
\text { Strategy } \\
\text { Processes }\end{array}$ & $\begin{array}{l}\text { Firm Level } \\
\text { Vision and } \\
\text { Strategy }\end{array}$ \\
\hline 4. Managed & $\begin{array}{l}\text { Managed } \\
\text { Process }\end{array}$ & UX Leadership & $\begin{array}{l}\text { Organizational } \\
\text { Ownership }\end{array}$ & UX Architect & $\begin{array}{l}\text { Strategic } \\
\text { Planning }\end{array}$ \\
\hline 3. Defined & $\begin{array}{l}\text { User Data } \\
\text { Provided to } \\
\text { Management }\end{array}$ & $\begin{array}{l}\text { Managed } \\
\text { Engagement }\end{array}$ & $\begin{array}{l}\text { Portfolio } \\
\text { Ownership } \\
\text { Management }\end{array}$ & $\begin{array}{l}\text { Integration } \\
\text { with Broader } \\
\text { Business } \\
\text { Processes }\end{array}$ & $\begin{array}{l}\text { Portfolio } \\
\text { Planning }\end{array}$ \\
\hline 2. Repeatable & $\begin{array}{l}\text { Qualitative and } \\
\text { Process }\end{array}$ & UX Operations & $\begin{array}{l}\text { Project } \\
\text { Manager Owns } \\
\text { Relationship }\end{array}$ & $\begin{array}{l}\text { Product } \\
\text { Development } \\
\text { Include UX } \\
\text { Processes }\end{array}$ & $\begin{array}{l}\text { Product } \\
\text { Planning }\end{array}$ \\
\hline 1. Initial & $\begin{array}{l}\text { UX Basic } \\
\text { Practices }\end{array}$ & $\begin{array}{l}\text { Staff with UX } \\
\text { Professionals }\end{array}$ & $\begin{array}{l}\text { UX } \\
\text { Professionals } \\
\text { Own } \\
\text { Relationship }\end{array}$ & $\begin{array}{l}\text { Localized } \\
\text { Product Dev } \\
\text { Team } \\
\text { Integration }\end{array}$ & $\begin{array}{l}\text { Localized } \\
\text { Product } \\
\text { Optimization }\end{array}$ \\
\hline
\end{tabular}

\subsection{Workshop Sessions}

In each of the work's three sessions, participants broke into groups to debate the issues that lie conceptually below each of the cells of the matrix. Each group considered one column (i.e. management practice) for a session. In the succeeding sessions, each group considered other columns in order to generate fresh ideas and to stimulate debate.

At the final wrap-up session the authors led a discussion to summarize, compare results, initially resolve conflicts, and revise terminology. The authors presented a summary of the day's results at a post-workshop presentation at the UPA 2009 conference.

Following the workshop, the authors revised the model further and posted the results on the Web as a report. This report incorporated not only the results of the workshop, but also details of the process from which those results were obtained. The report appears publicly on the Usability in the Enterprise project page of the UPA 
Website (www.usabilityprofessionals.org), further plans call for announcements to be made in UPA publications to its membership as well as other venues.

\section{Discussion}

The authors plan to incorporate feedback from subsequent presentations, such as the session at HCII 2009, into the U/UX Maturity Model and to make a revised version public. In general, the authors hope to further articulate and generalize the maturity model so that it might be use for benchmarking U/UX across the industry.

\section{Acknowledgements}

The authors acknowledge the assistance of staff/associates from Ovo Studios, LLC, and Aaron Marcus and Associates, Inc., for providing documents and human resources to assist in the Workshop and in preparation of this paper. In particular, Marcus would like to thank Mr. Niranjan Krishnamurthi, AM+A Designer/Analyst, for his assistance in preparing this document.

\section{References}

1. European Design Centre. User-Centred Design Works (CD-ROM). Publisher: IOP Human Machine Interaction, This CD-ROM presents a case for user-centered design including case studies and information resources (2004), http: / /www. edc.nl

2. Cunningham, J.P., Cantor, J., Pearsall, S.H., Richardson, K.H.: Industry Briefs: AT+T. Interactions 8(2), 27-31 (2001)

3. Gunther, R.G., Butler, S.A., Dove, L., Gutierrez, P.V., Marine, L.: The Business of Usability: Developing Metrics to Justify our Existence and Budgets. In: UPA Conference, Broomfield, CO (2006)

4. Gunther, R.G., Marcus, A., Sieffert, R.: How mature is your company's UX capability?: A capability modeling workshop. In: UPA Conference, Portland, OR (2009)

5. Gunther, R., Binhack, A., Dodd, J., Mischke, A., Kerkow, D.: An Analysis of ROI Measurement and Metrics across Usability Professionals (2005),

http: / / www . upassoc.org

6. Marcus, A.: Global/Intercultural User-Interface Design. In: Jacko, J., Spears, A. (eds.) Handbook of Human-Computer Interaction, 3rd edn., ch. 18, pp. 355-380. Lawrence Erlbaum Publishers, New York (2007)

7. Marcus, A.: Cross-Cultural User-Interface Design Patterns for Mobile Products in Japan, Taiwan, and the USA. Aaron Marcus and Associates, Inc., Internal Presentation (2007)

8. Marcus, A.: User Interface Design's Return on Investment: Examples and Statistics. In: Bias, R.G., Mayhew, D.J. (eds.) Cost-Justifying Usability, 2nd edn., ch. 2, pp. 17-39. Elsevier, San Francisco (2005)

9. Marcus, A.: What Would an Ideal CHI Education Look Like? Fast Forward Column, Interactions 12(5), 54-55 (2005)

10. Marcus, A.: Usability Grows Up: The Great Debate. Fast Forward Column, Interactions 12(4), 72-73 (2005) 
11. Marcus, A.: User-Centered Design in the Enterprise. Fast-Forward Column, Interactions 13(1), 18-23 (2005)

12. Marcus, A.: Dare We Define User-Interface Design. Fast-Forward Column, Interactions 9, 31-36 (2002), http: / / www . acm.org

13. Marcus, A., Baumgartner, V.J.: Mapping User-Interface Design Components vs. Culture Dimensions in Corporate Websites. Visible Language Journal 38(1), 1-65 (2004)

14. Marcus, A., Gould, E.W.: Cultural Dimensions and Global Web User-Interface Design: What? So What? Now What? In: Proc., 6th Conference on Human Factors and the Web, June 19. University of Texas, Austin (2000), http: / /www . tri.sbc . com/hfweb

15. Marcus, A.: Graphical User-Interfaces. In: Helander, M., Landauer, T.K., Prabhu, P.V. (eds.) Handbook of Human-Computer Interaction, ch. 19, pp. 423-444. Elsevier, Amsterdam (1997)

16. Marcus, A., Baumgartner, V.J.: A Practical Set of Culture Dimension for Evaluating UserInterface Designs. In: Masoodian, M., Jones, S., Rogers, B. (eds.) APCHI 2004. LNCS, vol. 3101, pp. 252-261. Springer, Heidelberg (2004)

17. Schaeffer, E.: Institutionalization of Usability. Addison-Wesley, Reading (2004)

18. Vredenburg, K., Insensee, S., Righi, C.: User-Centered Design: An Integrated Approach. Software Quality Institute Series. Prentice Hall, Upper Saddle River (2002)

19. I.I.: 13407 Human-centred design processes for interactive systems. ISO 13407: 1999 (1999)

20. ISO: ISO 18529 Human-centred design processes for interactive systems. ISO 18529 TR: 2000 (2000)

21. Earthy, J.: Usability Maturity Model: Processes. TRUMP Technical Report (1999), http://usabilitynet.org/trump/trump/index.htm

22. Jokela, T.: Assessments of Usability Engineering Processes: Experiences from Experiments. In: IEEE: HICSS Proceedings (2003)

23. Jokela, T., Abrahamsson, P.: Modelling Usability Capability - Introducing the Dimensions. In: Bomarius, F., Oivo, M. (eds.) PROFES 2000. LNCS, vol. 1840, pp. 73-87. Springer, Heidelberg (2000) 